\title{
RESENSI PUISI KREATIF KARYA AGUNG PURNOMO
}

\section{Erwinda Eka Prastyawati}

Universitas Nahdlatul Ulama Sidoarjo

\section{PENGANTAR}

Puisi adalah kumpulan kata-kata yang diucapkan atau ditulis yang mengekspresikan ide atau emosi dengan gaya yang jelas dan imajinatif. Puisi terdiri dari pola ritme dan metrik tertentu. Sebenarnya, ini adalah teknik sastra yang berbeda dari prosa atau ucapan biasa, karena itu dalam pola metrik atau dalam sajak bebas (Literary Devices, 2019). Kadang-kadang suatu tugas belajar membutuhkan penyelidikan puisi kontemporer dan kreatif. Menemukan informasi tentang penyair atau puisi baru seringkali sulit. Ada beberapa strategi untuk membangun kerangka kerja untuk penelitian, menggunakan Sumber Daya Perpustakaan dan menemukan sumber daya untuk mendukung tugas resensi puisi (Huff, 2019). Resensi puisi dapat membantu 
pembaca memahami arah tulisan sang penyair (Moore, 2019).

\section{AGUNG PURNOMO}

Penyair Agung Purnomo lahir di Sidoarjo pada 3 November 1981. Beliau berprofesi sebagai seorang dosen di Indonesia. Profesi sebagai dosen mendorong penulis untuk kreatif menghasilkan karya tulisan. Beberapa tulisan beliau telah diseminasikan secara luas melalui penerbit nasional, yaitu: ITB Press, UNUSIDA Press, dan STIEBA Madura Press.

\section{KARYA}

Mengenali dan menyelami perenungan Agung Purnomo bisa dilakukan pembaca lewat beberapa karya puisinya. Agung Purnomo menyampaikan keyakinan dan kemampuannya menceritakan episode hidup melalui diantaranya dalam judul: sepekan awal tanpamu, cantik, berpulang, bapak Samsuri, menyala, tangisnya, pandai, rindu di ubun-ubun, kita, dua kaki dan \#CH1.

Puisi menjadi gambaran pikiran seorang kreatornya. Penyair melalui puisinya kadang kala menyampaikan gagasan, kenangan, kritikan, atau 
harapan lewat kata-kata yang indah. Demikian juga dengan penyair pria bernama Agung Purnomo.

MENYALA

\begin{tabular}{|l|l|}
\hline \multicolumn{1}{|c|}{$\begin{array}{c}\text { Identitas } \\
\text { Buku }\end{array}$} & \multicolumn{1}{c|}{ Keterangan } \\
\hline Judul Puisi & Menyala \\
\hline Penulis & Agung Purnomo \\
\hline Jenis Puisi & Puisi Haiku \\
\hline Judul Buku & Tenta Kimaya \\
\hline Penerbit & STIEBA Madura Press \\
\hline Tahun & 2019 \\
\hline ISBN & $978-602-53090-9-0$ \\
\hline
\end{tabular}

Puisi berjudul Menyala dalam buku Tenta Kimaya tersebut mengisahkan proses bekerja menggunakan gawai terus menerus sebagai ciri khas generasi modern. Penulis Agung Purnomo dan Nur Asitah memakai teknik puisi Haiku dengan formula khusus dari Jepang untuk menggali puisi (Purnomo, 2019b). 


\section{BERPULANG}

\begin{tabular}{|l|l|}
\hline \multicolumn{1}{|c|}{$\begin{array}{c}\text { Identitas } \\
\text { Buku }\end{array}$} & \multicolumn{1}{c|}{ Keterangan } \\
\hline Judul Puisi & Berpulang \\
\hline Penulis & Agung Purnomo \\
\hline Jenis Puisi & Puisi Epitaf \\
\hline Judul Buku & Syair Nimala \\
\hline Penerbit & STIEBA Madura Press \\
\hline Tahun & 2019 \\
\hline ISBN & $978-623-90413-1-1$ \\
\hline
\end{tabular}

Mencengkeramai buku sajak bertajuk Berpulang dalam buku Syair Nimala karya kolaborasi Agung Purnomo membangun banyak kesan dan rasa untuk mengingat kematian lebih dalam. Paragraf disusun beralur sesuai khas puisi Epitaf untuk mengenang kematian (Purnomo, 2019a). 


\section{KITA}

\begin{tabular}{|l|l|}
\hline \multicolumn{1}{|c|}{$\begin{array}{c}\text { Identitas } \\
\text { Buku }\end{array}$} & \multicolumn{1}{|c|}{ Keterangan } \\
\hline Judul Puisi & Kita \\
\hline Penulis & $\begin{array}{l}\text { Agung Purnomo, Elsa } \\
\text { Rosyidah }\end{array}$ \\
\hline Jenis Puisi & Puisi Bebas \\
\hline Judul Buku & Suweda Ate \\
\hline Penerbit & STIEBA Madura Press \\
\hline Tahun & 2019 \\
\hline ISBN & $978-602-53090-5-2$ \\
\hline
\end{tabular}

Puisi karya kolaborasi antara Agung

Purnomo dan Elsa Rosyidah ini yang berjudul Kita dalam buku bertajuk Suweda Ate ini mengisahkan perjalanan pasangan hidup dalam arungi rumah tangga selama 10 tahun. Penulis memakai teknik puisi bebas agar lebih bisa mengeksplorasi diri (Purnomo \& Rosyidah, 2019). 


\section{RINDU DI UBUN-UBUN}

\begin{tabular}{|l|l|}
\hline \multicolumn{1}{|c|}{$\begin{array}{c}\text { Identitas } \\
\text { Buku }\end{array}$} & \multicolumn{1}{c|}{ Keterangan } \\
\hline Judul Puisi & Rindu di Ubun-ubun \\
\hline Penulis & Agung Purnomo \\
\hline Jenis Puisi & Puisi Bebas \\
\hline Judul Buku & Rassana Jlantir \\
\hline Penerbit & STIEBA Madura Press \\
\hline Tahun & 2019 \\
\hline ISBN & $978-602-53090-6-9$ \\
\hline
\end{tabular}

Sang penulis ingin menghubungkan kerinduan dengan beragam aspek kehidupan dunia. Kesibukan membuat kita sering melupakan banyak hal sehingga kadang merasa rindu terhadap hal tersebut (Purnomo, 2019c). 


\section{\#CH1}

\begin{tabular}{|l|l|}
\hline \multicolumn{1}{|c|}{$\begin{array}{c}\text { Identitas } \\
\text { Buku }\end{array}$} & \multicolumn{1}{c|}{ Keterangan } \\
\hline Judul Puisi & \#CH1 \\
\hline Penulis & Agung Purnomo \\
\hline Jenis Puisi & Puisi Bebas \\
\hline Judul Buku & Kidung Nawala (Jilid 1) \\
\hline Penerbit & UNUSIDA Press \\
\hline Tahun & 2018 \\
\hline ISBN & $978-602-51116-7-9$ \\
\hline
\end{tabular}

Maka begitulah sang penulis Agung Purnomo berusaha membawa pembaca untuk mengenang dan menghormati jejak Kiper Persela Lamongan bernama Choirul Huda. $\mathrm{CH} 1$ meninggal tatkala bertanding. Penulis berusaha keras menyoroti kondisi sang tokoh (Purnomo, 2018a). 


\section{BAPAK SAMSURI}

\begin{tabular}{|l|l|}
\hline \multicolumn{1}{|c|}{$\begin{array}{c}\text { Identitas } \\
\text { Buku }\end{array}$} & \multicolumn{1}{c|}{ Keterangan } \\
\hline Judul Puisi & Bapak Samsuri \\
\hline Penulis & Agung Purnomo, Nur Asitah \\
\hline Jenis Puisi & Puisi Clerihew \\
\hline Judul Buku & Dhalubang Marta \\
\hline Penerbit & STIEBA Madura Press \\
\hline Tahun & 2019 \\
\hline ISBN & $978-623-90413-0-4$ \\
\hline
\end{tabular}

Puisi dalam buku Dhalubang Marta yang berjudul Bapak Samsuri karya Agung Purnomo dan Nur Asitah lebih menitikberatkan pada proses melucukan kegiatan sang tokoh cerita. Jika dibaca secara keseluruhan, puisi ini sangat menarik dan dan lucu sebab asosiasikan tokoh dengan kucing. Puisi memakai teknik Clerihew (Purnomo \& Asitah, 2019a). 


\section{TANGISNYA}

\begin{tabular}{|l|l|}
\hline \multicolumn{1}{|c|}{$\begin{array}{c}\text { Identitas } \\
\text { Buku }\end{array}$} & \multicolumn{1}{c|}{ Keterangan } \\
\hline Judul Puisi & Tangisnya \\
\hline Penulis & Agung Purnomo, Nur Asitah \\
\hline Jenis Puisi & Puisi Naratif \\
\hline Judul Buku & Bhumi Bawera \\
\hline Penerbit & STIEBA Madura Press \\
\hline Tahun & 2019 \\
\hline ISBN & $978-602-53090-8-3$ \\
\hline
\end{tabular}

Puisi berjudul Tangisnya mengangkat tema oleh Agung Purnomo dan Nur Asitah tentang manusia di dunia secara naratif (Purnomo \& Asitah, 2019e). 


\section{PANDAI}

\begin{tabular}{|l|l|}
\hline \multicolumn{1}{|c|}{$\begin{array}{c}\text { Identitas } \\
\text { Buku }\end{array}$} & \multicolumn{1}{c|}{ Keterangan } \\
\hline Judul Puisi & Pandai \\
\hline Penulis & Agung Purnomo, Nur Asitah \\
\hline Jenis Puisi & Puisi Riddle \\
\hline Judul Buku & Tolesan Aditi \\
\hline Penerbit & STIEBA Madura Press \\
\hline Tahun & 2019 \\
\hline ISBN & $978-602-53090-7-6$ \\
\hline
\end{tabular}

Penulis Agung Purnomo dan Nur Asitah terlihat ingin membuat pembaca menjadi berpikir. Dari segi isi puisi tersebut menggambarkan sebuah renungan dirinya tentang gawai. Dari cara penyair memaparkan isi hatinya, puisi Pandai di Ubun-ubun sangat tepat dan menarik (Purnomo \& Asitah, 2019c). 


\section{DUA KAKI}

\begin{tabular}{|l|l|}
\hline \multicolumn{1}{|c|}{$\begin{array}{c}\text { Identitas } \\
\text { Buku }\end{array}$} & \multicolumn{1}{c|}{ Keterangan } \\
\hline Judul Puisi & Dua Kaki \\
\hline Penulis & Agung Purnomo \\
\hline Jenis Puisi & Puisi Bebas \\
\hline Judul Buku & Kidung Nawala (Jilid 2) \\
\hline Penerbit & UNUSIDA Press \\
\hline Tahun & 2018 \\
\hline ISBN & $978-602-51116-8-6$ \\
\hline
\end{tabular}

Puisi diatas mengangkat tema tentang perjuangan bertahan hidup diantara beberapa pilihan. Kebingungan yang harus sering kita jalani tatkala harus memilih (Purnomo, 2018b). 


\section{SEPEKAN AWAL TANPAMU}

\begin{tabular}{|l|l|}
\hline \multicolumn{1}{|c|}{$\begin{array}{c}\text { Identitas } \\
\text { Buku }\end{array}$} & \multicolumn{1}{c|}{ Keterangan } \\
\hline Judul Puisi & Sepekan Awal Tanpamu \\
\hline Penulis & Agung Purnomo, Nur Asitah \\
\hline Jenis Puisi & Puisi bersekuen \\
\hline Judul Buku & Arebhan Helai \\
\hline Penerbit & STIEBA Madura Press \\
\hline Tahun & 2019 \\
\hline ISBN & $978-623-90413-3-5$ \\
\hline
\end{tabular}

Puisi ini menceritakan tentang kejadian ketidakhadiran seorang kekasih selama seminggu. Dari hari senin hingga minggu. Dari Sedih hingga bahagia kembali. Alur gunakan puisi bersekuen ala hari. Sungguh menarik tak hanya sekedar hiburan (Purnomo \& Asitah, 2019d). 


\section{CANTIK}

\begin{tabular}{|l|l|}
\hline \multicolumn{1}{|c|}{$\begin{array}{c}\text { Identitas } \\
\text { Buku }\end{array}$} & \multicolumn{1}{c|}{ Keterangan } \\
\hline Judul Puisi & Cantik \\
\hline Penulis & Agung Purnomo, Nur Asitah \\
\hline Jenis Puisi & Puisi Jenaka Limerick \\
\hline Judul Buku & Lembhar Jiwana \\
\hline Penerbit & STIEBA Madura Press \\
\hline Tahun & 2019 \\
\hline ISBN & $978-623-90413-2-8$ \\
\hline
\end{tabular}

Dalam buku berjudul Lembhar Jiwana dengan puisi berjudul Cantik ini Agung Purnomo menggandeng Nur Asitah berusaha menghibur para pembaca dengan puisi jenaka Limerick (Purnomo \& Asitah, 2019b).

\section{PENUTUP}

Puisi-puisi karya Agung Purnomo mampu menceritakan episode hidup yang menarik dan lucu melalui judul: sepekan awal tanpamu, cantik, berpulang, bapak Samsuri, menyala, tangisnya, pandai, rindu di ubun-ubun, kita, dua kaki dan \#CH1. 


\section{REFERENCES}

Huff, D. (2019). Methods to Analyze Contemporary

Poem. Retrieved June 21, 2019, from

https://libguides.scf.edu/contemporary_poetry_p oems_comparison

Literary Devices. (2019). Poem. Retrieved June 20, 2019, from https://literarydevices.net/poem/ Moore, M. (2019). Poetry Summary and Analysis of "Poetry." Retrieved June 22, 2019, from https://www.gradesaver.com/poetry/studyguide/summary-poetry

Purnomo, A. (2018a). \#CH1. In Kidung Nawala (Jilid 1). Sidoarjo: UNUSIDA Press.

Purnomo, A. (2018b). Dua Kaki. In Kidung Nawala (Jilid 2). Sidoarjo: UNUSIDA Press.

Purnomo, A. (2019a). Berpulang. In Syair Nimala.

Sumenep: STIEBA Madura Press.

Purnomo, A. (2019b). Menyala. In Tenta Kimaya.

Sumenep: STIEBA Madura Press.

Purnomo, A. (2019c). Rindu di Ubun-Ubun. In Rassana Jlantir. Sumenep: STIEBA Madura Press.

Purnomo, A., \& Asitah, N. (2019a). Bapak Samsuri. In

Dhalubang Marta. Sumenep: STIEBA Madura Press.

Purnomo, A., \& Asitah, N. (2019b). Cantik. In Lembhar Jiwana. Sumenep: STIEBA Madura Press.

Purnomo, A., \& Asitah, N. (2019c). Pandai. In Tolesan Aditi. Sumenep: STIEBA Madura Press. 
Purnomo, A., \& Asitah, N. (2019d). Sepekan Awal

Tanpamu. In Arebhan Helai. Sumenep: STIEBA

Madura Press.

Purnomo, A., \& Asitah, N. (2019e). Tangisnya. In

Bhumi Bawera. Sumenep: STIEBA Madura Press.

Purnomo, A., \& Rosyidah, E. (2019). Kita. In Suweda

Ate. Sumenep: STIEBA Madura Press. 